GOSPODARKA SUROWCAMI MINERALNYMI - MINERAL RESOURCES MANAGEMENT

\title{
Cathodoluminescence-revealed diagenesis of carbonates and feldspars in Cergowa sandstones (Oligocene), Outer Carpathians
}

\section{Introduction}

The Cergowa Beds were deposited by a variety of mass gravity flows as a submarine lenticular lithosome (Lower Oligocene) in the SE part of the Polish Flysch Carpathians (Ślączka and Unrug 1976). The lithosome consists of two lithofacies, namely sandstones and sandstones interbedded with shales. The sandstones display very favourable physical-mechanical properties (Peszat 1984; Peszat and Buczek-Pułka 1986; Pszonka et al. 2010); they possess high resistance to fragmentation (Los Angeles coefficient $\leq 20 \mathrm{v}$. $\leq 25 \%$ ), low and moderate resistance to abrasion/wear (micro-Deval coefficient $\leq 35 \%$ ), low absorption $(\leq 2 \%)$, and very high resistance to freezing and thawing $(\leq 1 \%$; Bromowicz et al. 1976). Therefore, they are used in the production of crushed aggregate - one of the most highly valued among industrially exploited sandstones of the Polish Carpathians (Peszat and Buczek-Pułka 1986; Nieć et al. 2003; Pszonka et al. 2010). On the basis of transmitted light microscopy, Peszat (1984) attributed the outstanding technological parameters to the presence of recrystallised carbonate components, but the details of the diagenetic processes that affected the Cergowa sandstones, and of their effects, remained unknown. Therefore,

* M.Sc., Mineral and Energy Economy Research Institute of the Polish Academy of Sciences, Kraków, Poland; e-mail: jpszonka@min-pan.krakow.pl

** Professor, AGH University of Science and Technology, Faculty of Geology, Geophysics and Environmental Protection, Kraków, Poland; e-mail: wendorff@agh.edu.pl 
the aim of this paper is to present our recent observations on the diagenetic features conducted under cathodoluminescence, casting new light and expanding the understanding of the processes responsible for such strong cementation of the Cergowa sandstones. Our observations may also have implications for hydrocarbon-related research into the Polish Carpathian successions.

The method that makes it possible to detect the results of the diagenetic processes and visualize relationships between the rock components is cathodoluminescence (CL) with cold cathode, which often reveals features not distinguished by other methods. It appears that the CL images of the Cergowa sandstones show luminescence colours mainly in carbonates and feldspars. Therefore, these two groups of minerals were chosen for this study. Such observations have not been conducted in the course of past petrologic studies of the Cergowa sandstones.

\section{Geological setting and mineral composition of the Cergowa sandstones}

The Cergowa Beds form a lenticular lithosome within the Menilite Formation (Lower Oligocene) and occur in two tectonic units of the Polish Flysch Carpathians - the Dukla Tectonic Unit and the southern part of the Silesian Tectonic Unit (Fig. 1A and 1B; Ślączka and Unrug 1976; Cieszkowski et al. 1990). The sandstone facies, called 'the Cergowa sandstones', constitute the main part of the Cergowa Beds.

Rock fragments predominate among the detrital components of the Cergowa sandstones, and their proportion ranges between 24.8 and 58.4\% (Peszat 1984). Carbonate grains prevail among lithoclasts of sedimentary rocks. Subordinate are grains of igneous and metamorphic rocks (granitoids, gneiss, and quartz-mica schist). Quartz accounts for $23-40 \%$ according to Ślączka and Unrug (1976) or 20-36\% according to Peszat (1984). Less common minerals are feldspars, the proportion of which does not exceed $10 \%$, and micas represented mainly by muscovite of average proportion below $11 \%$. Other components, i.e. heavy minerals, glauconite, carbonised plant detritus, and calcareous organic debris, occur in accessory proportions. Their average proportion seldom exceeds $1 \%$. The amount of cement, which Peszat (1984) determined as 'dolomitic-calcareous-clayey', is variable and ranges between 8.7 and $45.8 \%$. Peszat (1984) classified the rocks as greywackes; however, in comparison with the Pettijohn's classification, the Cergowa sandstones are lithic wackes and, in subordinate cases, lithic arenite (Pszonka 2009). The characteristic feature of these sandstones is the presence of organic matter; fragments of tree trunks occur in the thickest axial part of the lithosome, and fine plant detritus in its marginal parts. The highest concentrations of the coalified plant matter resulted in the accumulation of coal lenses. 

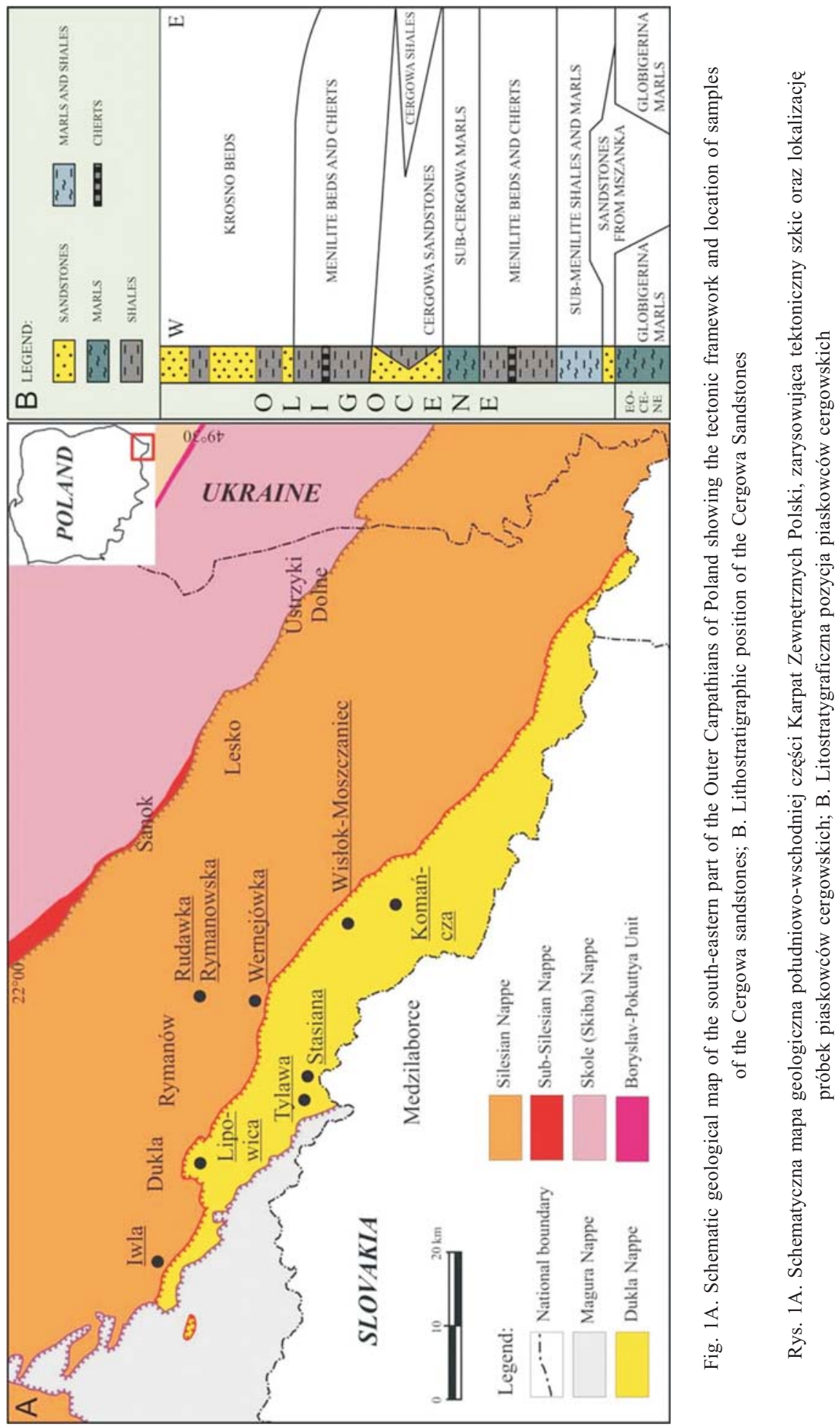


\section{Methods}

For thin section analysis, samples of the Cergowa sandstones were collected from outcrops at locations shown in Fig. 1A: Iwla, the Lipowica quarry, Tylawa, Stasiana, Rudawka Rymanowska, Wernejówka, Wisłok-Moszczaniec, and the Komańcza quarry. The cold cathode luminescence observations were carried out at the Institute of Geological Sciences, Jagiellonian University (Krakow, Poland). Forty thin sections were analysed with a cold cathode cathodoluminescence microscope CLmk3A CITL (UK) linked with a Nikon Eclipse 50i polarizing microscope. The voltage was $16-18 \mathrm{kV}$ and the electron beam intensity 700-800 $\mu \mathrm{A}$. Luminescence images were captured with a Canon EOS 50D digital video-camera.

General aspects of $\mathrm{CL}$ emissions and related features of feldspar and carbonate minerals observed under the cathodoluminescence are outlined below.

CL emissions of feldspars consist of three broad emission bands (Götze et al. 2000):

- blue emission - 420-500 nm,

- green emission - 540-570 nm,

- red emission - 690-760 nm.

Visual CL colour in calcic plagioclases is yellow, intermediate plagioclase appears green to yellow, and K-feldspars usually exhibit blue CL (Owen 1991). The green and yellow emissions are due to $\mathrm{Mn}^{2+}$ as an activator, the blue emission is caused by the substitution of $\mathrm{Al}^{3+}$ for $\mathrm{Si}^{4+}, \mathrm{Cu}^{2+}$, or $\mathrm{Ti}^{3+}$, or is associated with a hole on an oxygen adjacent to a divalent impurity ion $\left(\mathrm{Si}_{-}-\mathrm{O}^{-} \ldots \mathrm{M}^{2+}\right)$, whilst the red or infrared emissions result from $\mathrm{Fe}^{3+}$ (Götze et al. 2000). Rare earth elements (REE) are also potential activators of CL in feldspars, and their contents are usually higher in plagioclases than in K-feldspars (Götze et al. 1999). However, REEs rarely occur in sufficient amounts in natural feldspars to act as effective CL activators (Marshall 1988).

Visual CL colour in carbonates is mainly yellow, orange, red, or brownish. Almost all luminescence in carbonates is caused by trace elements as follows:

- activators $\mathrm{Mn}^{2+}$, RREs,

- sensitizers $\mathrm{Pb}^{2+}, \mathrm{Ce}^{3+}$,

- inhibitors $\mathrm{Fe}^{2+}, \mathrm{Fe}^{3+}, \mathrm{Ni}^{+}, \mathrm{Co}^{2+}$ (Machel 2000).

The main activator and inhibitor are $\mathrm{Mn}^{2+}$ and $\mathrm{Fe}^{2+}$, respectively. A higher concentration of $\mathrm{Mn}$ is probably responsible for self-quenching (Machel 2000).

Apart from trace elements and structural defects in crystals, the luminescence colour and intensity are controlled by the temperature and rate of crystal growth, the crystal surface structure, the composition and chemical equilibrium of pore waters, changes in $\mathrm{pH} / \mathrm{Eh}$, organic matter content, and the presence of clay minerals (Machel 2000).

Preliminary chemical analyses (64 analytical points) were performed in the same laboratory as the cold cathode luminescence observations, with an FE-SEM HITACHI S-4700 microscope equipped with EDS NORAN Vantage system. Photomicrographs were 
taken at an accelerating voltage of $20 \mathrm{keV}$, electron beam intensity of $10 \mu \mathrm{A}$, and a working distance of $12 \mathrm{~mm}$ with backscattered electrons detector (BSE).

\section{Observations}

\subsection{Carbonates in cathodoluminescence}

The most common colours shown in CL images by the carbonate components of the Cergowa sandstones are orange, dark brown, brown, and yellow; red colour occurs infrequently. Carbonate cement occurs as two types of sparite, and rarely microsparite, filling pore spaces and replacing some components of sandstones. The first type, which appears brown to dark orange in colour, is labelled here as $\mathrm{CC} 1$ and called 'brown' throughout the text (Fig. 2A). The CC1 constitutes the main filling of the pore spaces. Another type is light orange in colour, labelled CC2 and called 'orange' (Fig. 2A). The CC2 very often forms tiny rims around pore spaces filled with brown carbonate cement $(\mathrm{CC} 1)$, fills interboundary pores between brown sparite cement crystals (CC1), and partially or entirely fills out pore spaces. These two types of carbonate cement, $\mathrm{CC} 1$ and $\mathrm{CC} 2$, may occur together. In such cases, the boundaries between them range from sharp to diffuse either due to rapid or gradual changes in colour and luminescence intensity. Occasionally, the carbonate cement reveals $\mathrm{CL}$ colours yellow and bright yellow, which are labelled CC3 and called 'yellow' throughout the text (Fig. 2A). The CC3 cement partially fills out the remaining pore spaces, which were not filled by $\mathrm{CC} 1$ and $\mathrm{CC} 2$. Representative examples of the SEM reconnaissance analyses of the Cergowa sandstones show that all three cement types $(\mathrm{CC} 1, \mathrm{CC} 2$, and $\mathrm{CC} 3)$ are composed of calcite. These cement generations are invisible in polarized light images (Fig. 2B i 2C).

\subsection{Feldspars in cathodoluminescence}

Despite the fact that feldspars in the Cergowa sandstones constitute only $1.2-6.8 \%$ of the rock volume (Peszat 1984), these mineral grains appear in CL images as one of the most visually striking components because of distinct luminescence colours. K-feldspar shows here blue luminescence while plagioclase, which occurs as a subordinate type of feldspar, shows green and greenish luminescence (Fig. 3).

A characteristic feature of feldspar grains in the Cergowa sandstones are occurrences of weak- and non-luminescent areas, which occur mainly along fissures, cleavage traces within fractured grains (Fig. 3), and also as incomplete rims around grains (Fig. 4).

Where dark areas prevail, the CL images reveal relics after original feldspar grains (Fig. 5), the feature invisible in polarized light images (Figs 5 and 6). The SEM reconnaissance analyses reveal albitization of K-feldspars. 

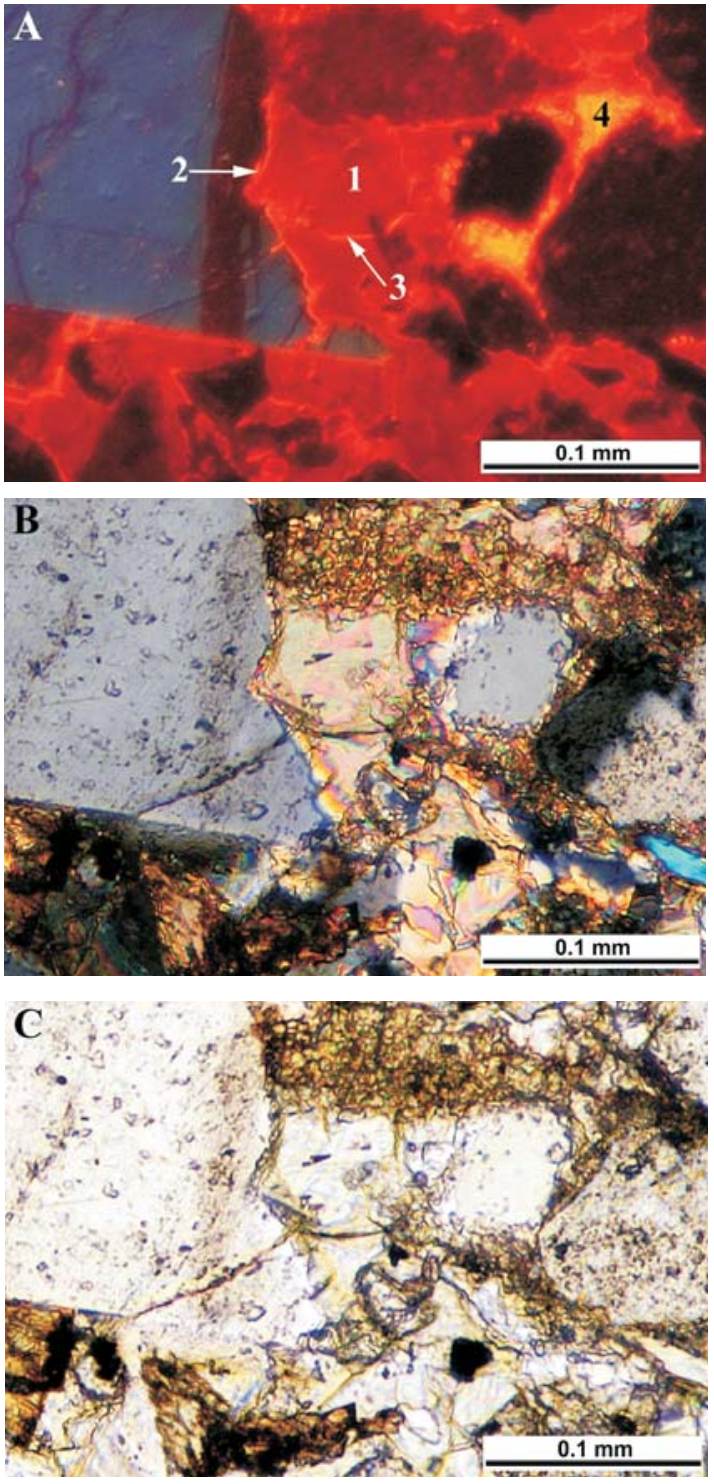

Fig. 2A. CL image. Three types of carbonate cement: $\mathrm{CC} 1$ brown in colour is the main type filling pore spaces (1), orange CC2 forms rims around pore spaces (2) and fills interboundary pores (3), and yellow CC3 fills the remaining pore spaces (4);

B. The same as Fig. 2A. in crossed-polarized light; C. The same as Fig. 2A and B. in plane-polarized light

Rys. 2A. Obrazy CL. Trzy generacje cementu węglanowego: CC1 (brązowa barwa) będący głównym rodzajem cementu wypełniającego (1), CC2 (pomarańczowa barwa) tworzący obwódki dookoła przestrzeni porowych (2) oraz wypełniający przestrzenie międzyporowe (3), CC3 (żółta barwa) wypełniający pozostałe przestrzenie porowe (4);

B. Ten sam obraz co w rysunku 2A, przedstawiony w spolaryzowanym świetle przy skrzyżowanych nikolach; C. Ten sam obraz co w rysunkach $2 \mathrm{~A}$ i $2 \mathrm{~B}$, przedstawiony w spolaryzowanym świetle przy równoległych nikolach 


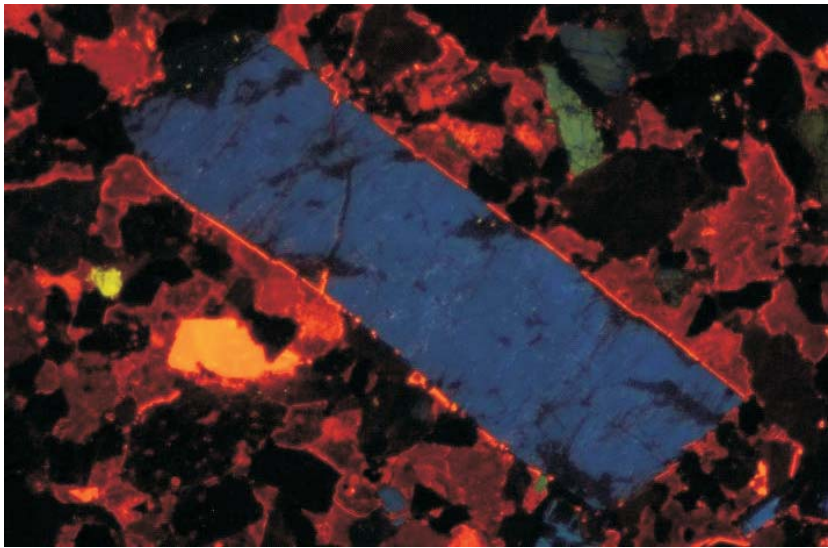

Fig. 3. CL image: K-feldspar (blue) and plagioclase (greenish) with dark, non-luminescent areas within the feldspar grains. Note orange rim of calcite (CC2) replacing marginal part of the K-feldspar and penetrating into traces of cleavage. Width of the field of view is $1.1 \mathrm{~mm}$ in all figures 3-12

Rys. 3. Obraz CL: skaleń potasowy (niebieski) oraz plagioklaz (zielonkawy) z ciemnymi, niewykazującymi luminescencji partiami w ziarnach. Pomarańczowa obwódka kalcytowa zastępuje marginalną część skalenia potasowego, penetrując wewnątrz ziarna. Szerokość obrazu wynosi $1,1 \mathrm{~mm}$ (dane dla rysunków 3-12)

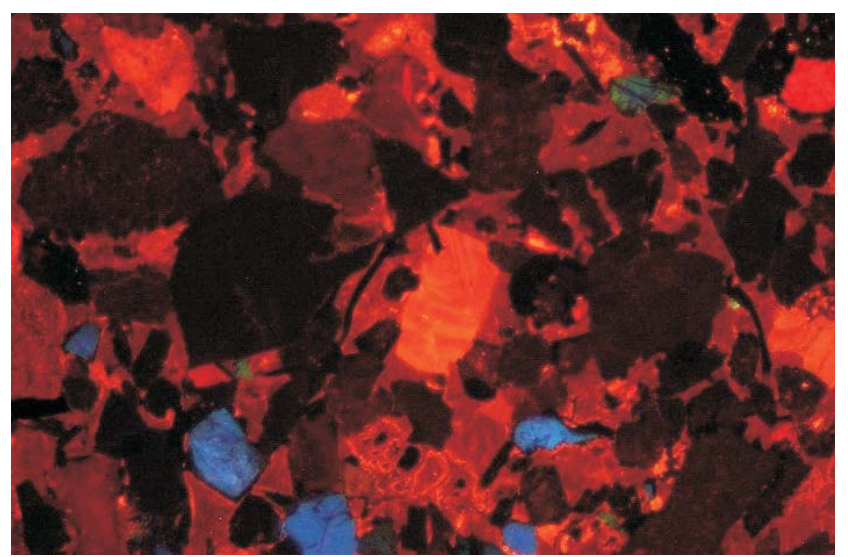

Fig. 4. CL image: K-feldspars (blue) with incomplete dark rims around grains

Rys. 4. Obraz CL: skalenie potasowe (niebieskie) z niekompletnymi ciemnym obwódkami dookoła ziaren

\subsection{Replacement of feldspars by carbonates in cathodoluminescence}

Clearly seen in the CL images are replacements of feldspar grains by carbonates (Fig. 7), which occur as zones, brown and orange in colour, that appear mostly along the marginal parts of feldspar grains, which often show irregularly corroded outlines. Carbonate 


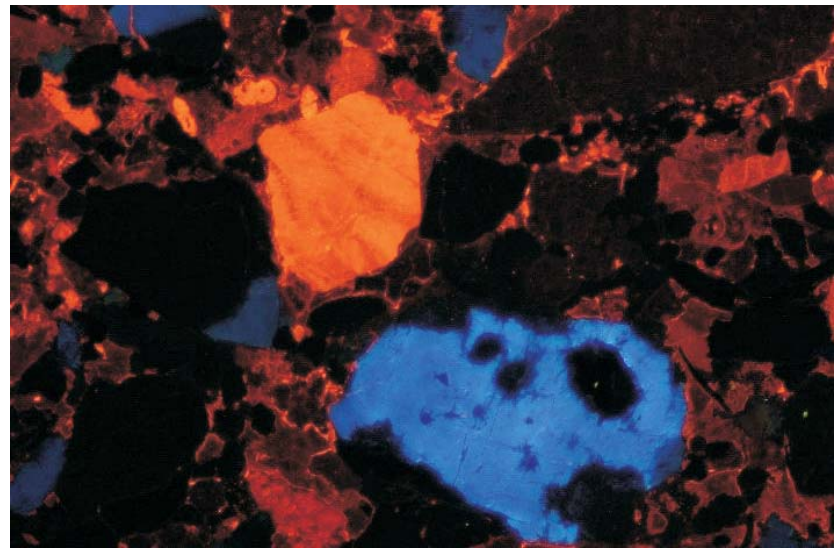

Fig. 5. CL image: Non-luminescent part (black) of altered K-feldspar within preserved blue-luminescent relic Rys. 5. Obraz CL: niewykazujące luminescencji przeobrażenia w skaleniu potasowym (niebieska barwa)

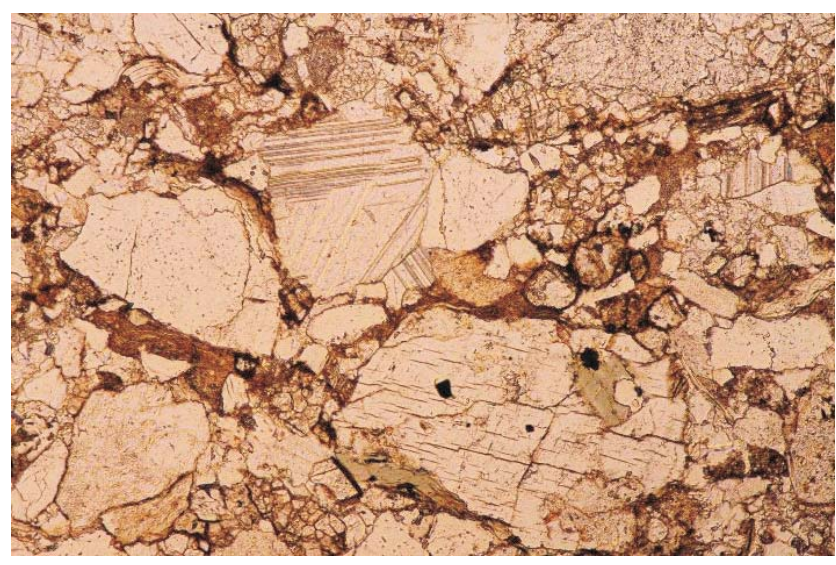

Fig. 6. The same as Fig. 5 in plane-polarized light

Rys. 6. Ten sam obraz co na rysunku 5, przedstawiony w spolaryzowanym świetle przy równoległych nikolach

replacement areas penetrate into feldspar grains through fissures and irregular dissolution embayments (Fig. 7).

Very highly advanced alteration results in patchy relics of feldspar 'floating' within carbonate (Fig. 8), and a complete replacement results in carbonate pseudomorphs after detrital feldspars (Fig. 9).

The cases of complete replacement of feldspar grains by carbonate are difficult to recognize in cathodoluminescence because no feldspar relics are visible. However, such replacements can be identified only by comparison of images viewed in CL with those analysed under PL crossed-polarized light, as the latter may show feldspar relics (Fig. 11). Plane-polarized light images are not useful in such cases (Fig. 12). 


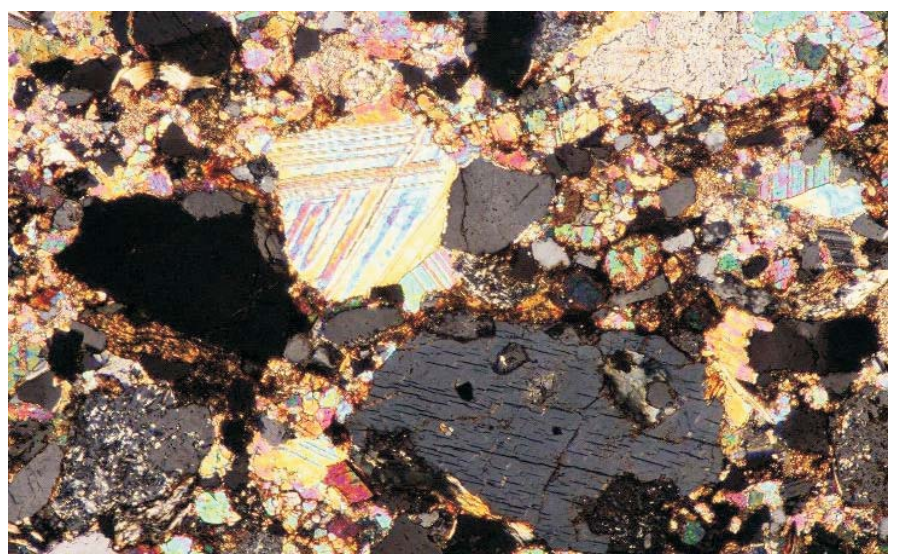

Fig. 7. The same as Fig. 5, in crossed-polarized light

Rys. 7. Ten sam obraz co na rysunkach 5 i 6 , przedstawiony w spolaryzowanym świetle przy skrzyżowanych nikolach

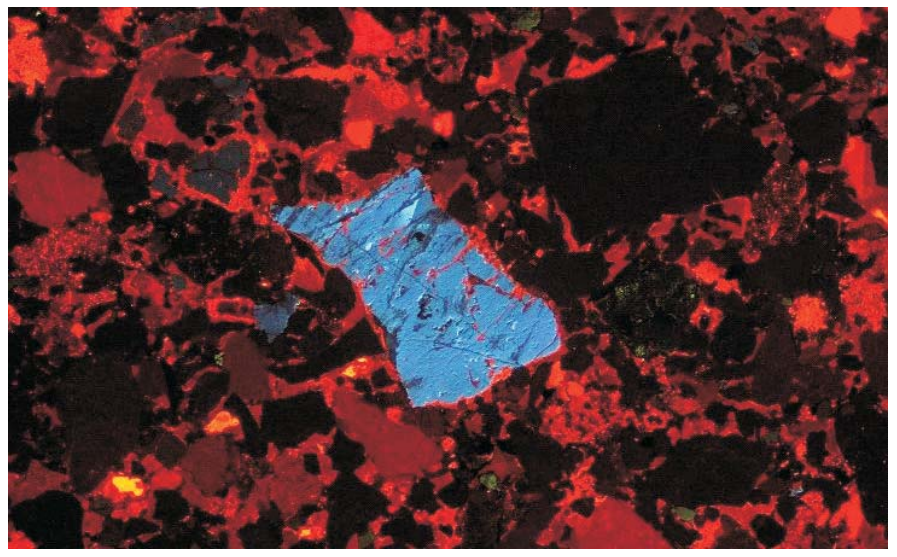

Fig. 8. CL image: partial replacement of K-feldspar (blue) by carbonate cement CC2 (bright orange) forming rim around irregularly corroded feldspar grain and penetrating into it along deep dissolution embayments

Rys. 8. Obraz CL: częściowe zastąpienie skalenia potasowego (niebieski) przez cement węglanowy CC2 (jasnopomarańczowy), tworzący nieregularną obwódkę dookoła skorodowanego ziarna

$$
\text { i penetrujący w głąb }
$$




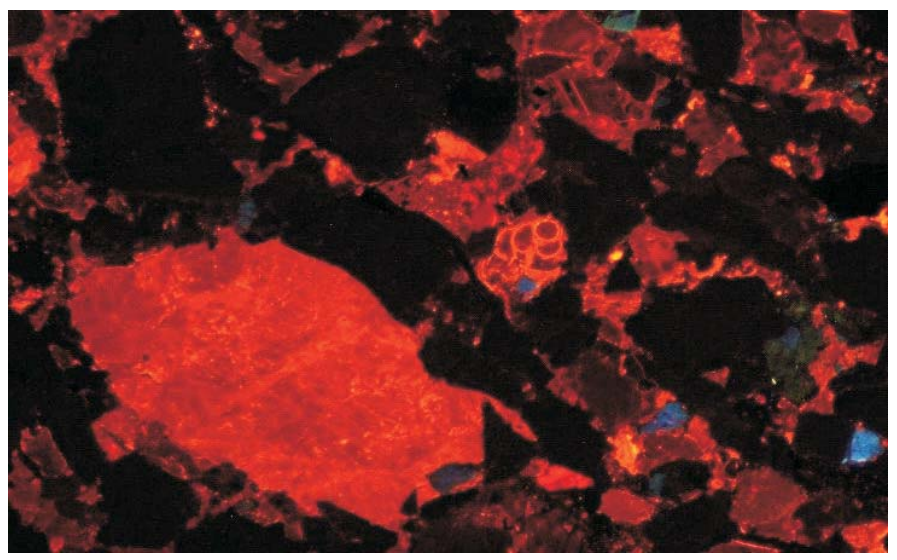

Fig. 9. CL image: Patchy relics of K-feldspars (bluish) 'floating' within carbonate (orange)

Rys. 9. Obraz CL: relikt skalenia potasowego (niebieski) w węglanie (pomarańczowy)

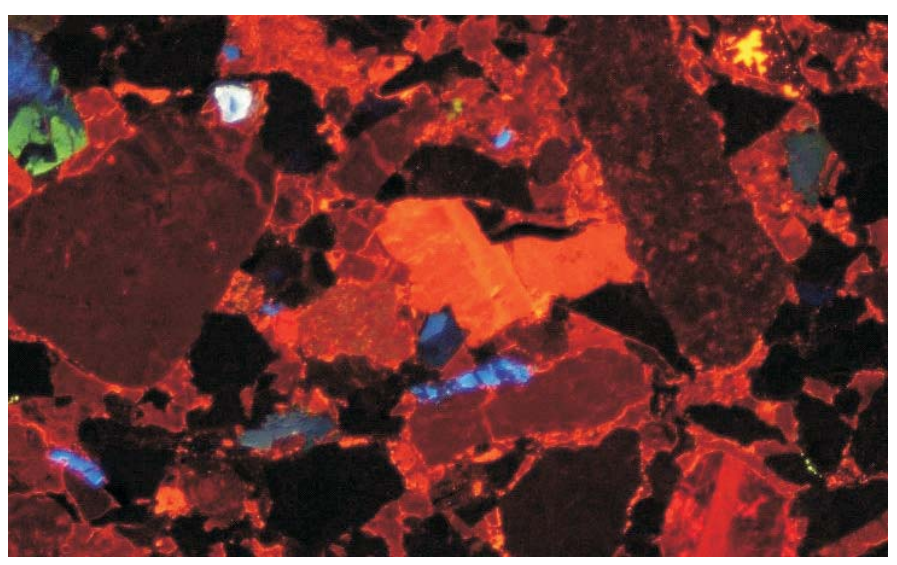

Fig. 10. CL image: Complete replacement of feldspar grain (in the centre) by carbonate (bright orange)

Rys. 10. Obraz CL: całkowite zastąpienie ziarna skalenia (w centralnej części obrazu) przez węglan (jasnopomarańczowa barwa)

\section{Interpretation and discussion}

\subsection{Carbonates}

Several generations of carbonate cement, which are not visible under the polarising microscope, were identified with cathodoluminescence. The main three types are brown (CC1), orange (CC2), and yellow (CC3), (Fig. 2). 


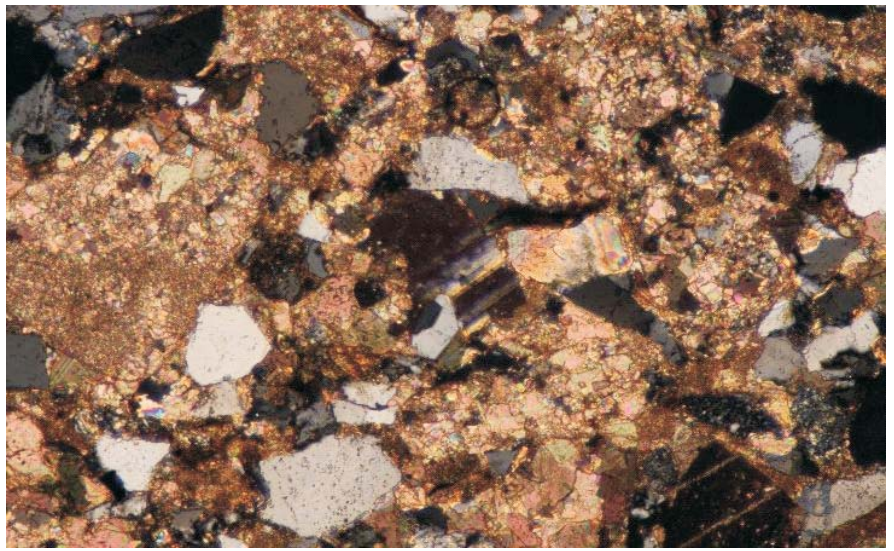

Fig. 11. The same as Fig. 10, in crossed-polarized light, still showing relics/'ghosts' of plagioclase twinning

Rys. 11. Ten sam obraz co na rysunku 10, przedstawiony w spolaryzowanym świetle przy skrzyżowanych nikolach, skalenie wykazują charakterystyczne zbliźniaczenia

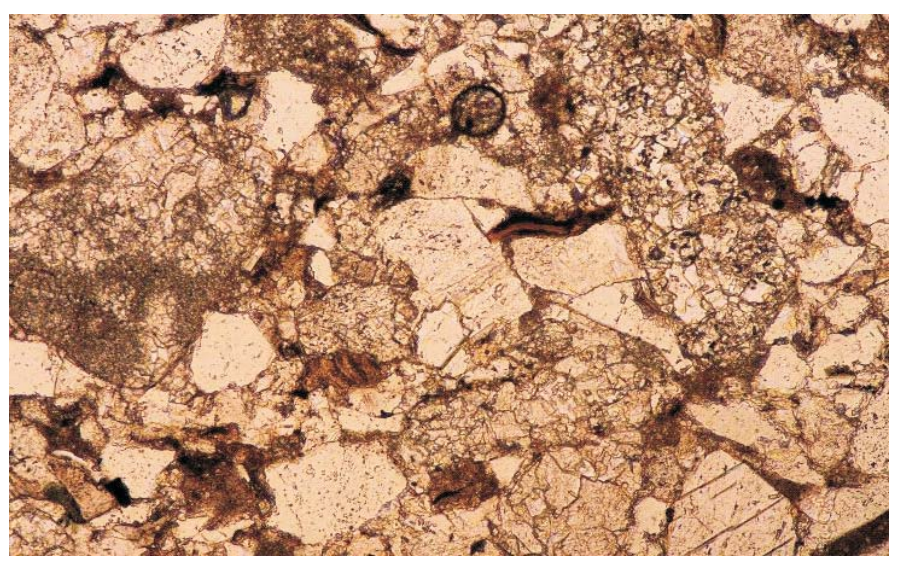

Fig. 12. The same as Fig. 10 and 11 in plane-polarized light

Rys. 12. Ten sam obraz co na rysunkach 10 i 11 , przedstawiony w spolaryzowanym świetle przy równoległych nikolach

Brown cement $(\mathrm{CC} 1)$ predominates and represents the oldest generation that crystallised in intergranular pore spaces and replaced dissolved parts of detrital grains (Fig. 2). Orange carbonate cement $(\mathrm{CC} 2)$ is younger and precipitated in the remaining pore spaces, within interboundary pores separating the brown cement sparite crystals, and in dissolved contact zones between detrital grains and brown cement (CC1) (Fig. 2). Both $\mathrm{CC} 1$ and $\mathrm{CC} 2$ generations are represented by calcite assigned by Pszonka and Wendorff (2013) to eoand/or mesodiagenesis.

Yellow cement (CC3) is the brightest and the youngest generation of carbonate, which crystallized at the stage of telodiagenesis (Pszonka and Wendorff 2013) in the existing pores 
that remained after precipitation of the two older cement generations (CC1-CC2; Fig. 4). Preliminary SEM analyses show that the $\mathrm{CC} 3$ cement is also composed of calcite. Its quantity is much lower than that of the older cements $(\mathrm{CC} 1$ and $\mathrm{CC} 2)$ because the earlier carbonate cements, related to eo- and mesogenesis, locally fill pores or preferentially block pore throats (Worden and Burley 2003). This reduces sandstone permeability and the volume of pores available to receive more cementing material.

\subsection{Feldspars}

Authigenic feldspar overgrowths reveal dark luminescence (Kastner 1971; Götze 1999, 2000). Consequently, the non-luminescent rims that do not penetrate into the feldspar grains observed in the Cergowa sandstones may be interpreted as authigenic overgrowths (Fig. 4).

The most common processes reducing the initial luminescence of feldspars are weathering and albitization (Milliken 2005; Gonzáles-Acebrón et al. 2012). Although the distinction between weathering and albitization based solely on colour intensity may often be unclear, the results of previous studies allow for preliminary identification based on petrography, as expressed by Gonzáles-Acebrón et al. (2012): 'weathered grains show dark luminescence mainly in their outer boundaries, which penetrates into the grain, whereas albitization preferentially occurs along fractures, twinning, and cleavages lines'. On this basis, and considering the observations presented in the previous section (Figs 3 and 5), it can be tentatively concluded that both processes-weathering and albitisation affected feldspar grains in the Cergowa sandstones. However, in order to confirm the effects of weathering or albitization, or to identify other alterations, knowledge of the chemical composition is required, e.g. by means of scanning electron microscopy (SEM). The reconnaissance SEM analyses carried out in the course of this study revealed that the analysed $\mathrm{K}$-feldspars were albitized. No weathering effects were revealed by SEM, but this does not mean that feldspar grains in the Cergowa sandstones are not affected by weathering processes, which should be expected, especially as the analysed samples were collected in outcrops. A more detailed geochemical study should be undertaken in the future to shed light on this problem.

\subsection{Replacement of feldspars by carbonates in cathodoluminescence}

Partial or total replacement of feldspar grains by calcite is a common diagenetic phenomenon in the Cergowa sandstones (Figs 8-10). Alkaline pore waters, enriched with $\mathrm{Ca}^{2+}$ cations and with $\mathrm{CO}^{2-}$ anions, had a destructive effect on the feldspars (and other silicate components), with simultaneous precipitation of carbonate material. Growth of calcite in place of pre-existing feldspar is clearly visible in the CL images of the Cergowa sandstones (Figs 8-10). In exceptional cases of extremely advanced replacement, cross-polarized light images (Fig. 11) are more useful in recognition of feldspar relics than the CL observations.

It can be inferred that the alkaline environment was favourable not only for feldspar dissolution but also for destruction of other terrigenous grains such as quartz or lithoclasts. 
The process of dissolution was moderate because usually only the edges of the grains were damaged by corrosion. Despite the low intensity, this process was very important in the sediment lithification. It resulted in the increased surface of corroded grains and therefore of the grain contact with the binder, which accounts for very strong cementation of the Cergowa sandstone components, manifested by their high hardness and resistance.

\section{Conclusions}

1. Three generations of carbonate cement binding the detrital components of the Cergowa sandstones were detected in the course of this study - brown (CC1), orange (CC2), and the youngest yellow (CC3); this distinction is not visible under a polarizing microscope.

2. Preliminary SEM analyses show that $\mathrm{CC} 1, \mathrm{CC} 2$, and $\mathrm{CC} 3$ cement generations are calcite.

3. Non-luminescent areas in feldspars are the result of albitization preliminarily confirmed by SEM analyses. The results of weathering should be expected but verification of that would require more detailed geochemical analyses.

4. Dissolution of the analysed detrital grains was important in lithification of the Cergowa sandstones by increasing the contact surface between the corroded grains and the cement; this contributed to very strong cementation emphasized by high resistance of the rock to abrasion.

5. Intense crystallisation of the pore-filling carbonate cements and replacement of corroded parts of feldspar grains very effectively reduced the porosity and permeability of the Cergowa sandstones, which is reflected by their high resistance to freezing and thawing.

6. This study shows that it is difficult to determine the nature of diagenetic changes by means of cold cathode CL without additional studies that would make it possible to reveal the chemical composition of minerals.

7. Further work, including geochemical investigations useful in detecting diagenetic alterations based on trace elements content, should be conducted in the future.

This research was supported by the Postgraduate Grant Scheme of the International Association of Sedimentologists (second session 2011)

\section{REFERENCES}

Bromowicz et al. 1976 - Bromowicz, J., Gucik, S. and Magiera, J. 1976. The Carpathian sandstones, their role as raw material and application perspectives. Zeszyty Naukowe Akademii Górniczo-Hutniczej, Geologia 2(2), pp. 1-91 (in Polish)

Cieszkowski et al. 1990 - Cieszkowski, M., Ślączka, A. and Zuchiewicz, W. 1990. Detailed Geological Map of Poland 1:50000, Jaśliska Sheet. Polish Geological Institute, Warszawa (in Polish). 
Götze et al. 1999 - Götze, J., Habermann, D., Neuser, R.D. and Richter, D.K. 1999. High-resolution cathodoluminesence spectrometric analysis of rare earth elements-activated cathodoluminescence in feldspar minerals. Chemical Geology 153, pp. 81-91.

Götze et al. 2000 - Götze, J., Krbetschek, M.R., Habermann, D. and Wolf, D. 2000. High-resolution cathodoluminescence studies of feldspar minerals [In:] Pagel, M., Barbin, V., Blanc, P., Ohnenstetter, D. eds. Cathodoluminescence in Geoscience, Springer, New York, pp. 245-270.

Gonzáles-Acebrón et al. 2012 - Gonzáles-Acebrón, L., Götze, J., Barca, D. and Arribas, J. 2012. Diagenetic albitization in the Tera Group, cameros Basin (NE Spain) recorded by trace elements and spectral cathodoluminescence. Chemical Geology 312, pp. 148-162.

Kastner, M. 1971. Authigenic feldspars in carbonate rocks. American Mineralogist 56, pp. 1403-1442.

Machel, H.G. 2000. Application of cathodoluminescence to carbonate diagenesis [In:] Pagel, M., Barbin, V., Blanc, P., Ohnenstetter, D. eds. Cathodoluminescence in Geoscience, Springer, New York, pp. 271-301.

Marshall, D.J. 1988. Cathodoluminescence of Geological Material. Winchester, Massachusetts: Allen and Unwin.

Milliken, K.L. 2005. Late diagenesis and mass transfer in sandstone-shale sequences [In:] Mackenzie, F.T. ed. Sediments, Diagenesis and Sedimentary Rocks, Treatise on Geochemistry 7, Elsevier, pp. 159-190.

Nieć et al. 2003 - Nieć, M., Górecki, J. and Szwed, E. 2003. Geological documentation (C category) of the „Lipowica II-1 ” sandstone deposit (unpublished), pp. 1-28 (in Polish).

Owen, M.R. 1991. Application of cathodoluminescence to sandstone provenance [In:] Backer, E.O., Koop, C.C. eds. Luminescence Microscopy: Quantitative and Qualitative Aspects, Society for Sedimentary Geology (SEPM) Short Course 25 Notes, Tulsa, pp. 67-75.

Peszat, C. 1984. Variations of mineral composition of the Cergowa sandstones in light of their deposition conditions and diagenetic alterations. Bulletin of the Polish Geological Institute 346 (24), pp. 207-234 (in Polish).

Peszat, C. and Buczek-Pułka, M. 1986. Znaczenie surowcowe piaskowców cergowskich na tle ich właściwości fizyczno-mechanicznych. Bulletin of the Polish Geological Institute 351, pp. 179-211.

Pszonka, J. 2009. The influence of sedimentation and diagenetic processes on economic significance of the Cergowa sandstones from "Lipowica II-1" deposit. Gospodarka Surowcami Mineralnymi - Mineral Resources Management 25 (3), pp. 333-342.

Pszonka et al. 2010 - Pszonka, J., Wendorff, M. and Kusaj, E. 2010. The Cergowa Sandstone as the most important raw material in the Podkarpackie Voivodeship. Bulletin of the Polish Geological Institute 439 (2), pp. 261-268 (in Polish).

Pszonka, J. and Wendorff, M. 2013. Cathodoluminescence as a tool in recognition of relations between components in the Cergowa sandstones (Oligocene, Outer Carpathians). Book of abstracts, Conference on Raman and Luminescence Spectroscopy in the Earth Sciences, July 3-6, 2013, Vienna, pp. 83-84. http://www.univie.ac.at/Mineralogie/Corals2013/docs/CORALS_Pszonka.pdf

Ślączka, A. 1971. Geologia jednostki dukielskiej. Prace Państwowego Instytutu Geologicznego 63, pp. 1-77 (in Polish).

Ślączka, A. and Unrug, R. 1976. Trends of textural and structural variation in turbidite sandstones: the Cergowa sandstone (Oligicene, Outer Carpathians). Annales Societatis Geologorum Poloniae 46, pp. 55-75.

Worden, R.H. and Burley, S.D. 2003. Sandstone diagenesis: the evolution of sand to stone [In:] Worden, R.H. and Burley, S.D., eds. Sandstone Diagenesis: Recent and Ancient, International Association of Sedimentologists, Reprint Series, pp. 3-44. 
KATODOLUMINESCENCJA JAKO NARZĘDZIE WIZUALIZUJĄCE PROCESY DIAGENETYCZNE WĘGLANÓW I SKALENI W PIASKOWCACH CERGOWSKICH (OLIGOCEN), KARPATY ZEWNĘTRZNE

\author{
Słowa kluczowe
}

katodoluminescencja, diageneza węglanów i skaleni, piaskowce cergowskie, surowce skalne

\title{
Streszczenie
}

Piaskowce cergowskie (dolny oligocen) charakteryzują się doskonałymi właściwościami fizykomechanicznymi, jednymi z najlepiej ocenianych wśród kruszyw budowlanych eksploatowanych w polskich Karpatach fliszowych. Obrazy katodoluminescencyjne piaskowców cergowskich przedstawiają przede wszystkim węglany i skalenie, dlatego te dwie grupy minerałów zostały wybrane, aby zaprezentować i lepiej zrozumieć procesy odpowiedzialne za wyjątkowo silną cementację detrytycznych komponentów skały. Katodoluminescencja (CL) z zimną katodą umożliwia obserwację i interpretację cech diagenetycznych węglanów i skaleni, wizualizuje relacje przestrzenne między szkieletem ziarnowym i cementem, a tym samym pozwala na lepsze zrozumienie genezy wysokich wartości parametrów technicznych piaskowców cergowskich. W piaskowcach cergowskich rozpoznano za pomocą katodoluminescencji z zimną katodą trzy generacje cementu węglanowego (kalcytowego) wypełniającego przestrzenie międzyziarnowe: kalcyt brązowy, kalcyt pomarańczowy i kalcyt żółty. Generacje te reprezentują spektrum od eo- przez mezo- po telodiagenezę. Skalenie zostały poddane procesom: albityzacji i zastępowania przez węglany. Dodatkowo, rozpuszczanie składników mineralnych wspomagane było ciśnieniem wywołanym kompakcją osadu. Proces rozpuszczania był na tyle słaby, że zniszczone zostały głównie brzeżne partie ziaren (korozja). Pomimo niedużej intensywności, proces ten był bardzo istotny w lityfikacji osadu. Przyczynił się on do zwiększenia powierzchni kontaktu korodowanych ziaren ze spoiwem. Kombinacja wspomnianych procesów spowodowała bardzo silną cementację składników piaskowców cergowskich, co przejawia się ich wysoką twardością i odpornością.

\section{CATHODOLUMINESCENCE-REVEALED DIAGENESIS OF CARBONATES AND FELDSPARS IN CERGOWA SANDSTONES (OLIGOCENE), OUTER CARPATHIANS}

$$
\text { Key words }
$$

cathodoluminescence, carbonate and feldspar diagenesis, Cergowa sandstones, mineral resources

\section{Abstract}

Cergowa sandstones (Lower Oligocene) have outstanding physical-mechanical properties, among the best of the industrial mineral deposits mined in the Polish Flysch Carpathians. Cathodoluminescence (CL) images of the Cergowa sandstones reveal luminescence colours mainly in carbonates and feldspars, therefore these two groups of minerals were chosen in order to gain a better understanding of the processes that resulted in exceptionally strong cementation of the detrital 
components. Cathodoluminescence with cold cathode made it possible to detect the diagenetic features of carbonates and feldspars, to visualize relationships between the detrital grains and cements, and to suggest the processes responsible for their origin and their influence on the physical properties of the Cergowa sandstones. Three generations of pore-filling carbonate cement - calcite - that display brown, orange, and yellow colours observed in CL represent the diagenetic spectrum from eo- through mezo- to telodiagenesis. The feldspars underwent albitization and partial, or even complete, replacement by calcite. Dissolution of marginal parts of the mineral grains resulted in corrosion, which increased the contact surface between the grains and the cement. A combination of these processes resulted in exceptionally strong cementation of the Cergowa sandstones, which is expressed by their very high hardness and resistance to abrasion, freezing, and thawing. 